\title{
Metafísica e finitude em Sartre
}

\author{
Metaphysics and Finitude in Sartre
}

\author{
* Marcelo Prates de Souza \\ ** Luiz Damon Santos Moutinho
}

\begin{abstract}
Resumo: Este artigo busca compreender qual o estatuto que a ideia de fundamento recebe na filosofia de Sartre enquanto uma ontologia existencial, isto é, enquanto uma filosofia que compreende o homem em sua finitude. Para isso, procura realizar uma análise da presença da Metafísica, sobretudo em O Ser e o Nada, com relação ao problema metafísico desenvolvido na obra: o surgimento do nada no ser. Por fim, procura, por meio desta análise, compreender o estatuto da finitude na mesma obra.
\end{abstract}

Palavras-chave: Metafísica. Ser. Fundamento. Finitude. Contingência.

\begin{abstract}
This article aims to understand which status the idea of foundation receives in Sartre's philosophy as an existential ontology, ie, as a philosophy that understands man in its finitude. For so, it aims to make an analysis of the presence of Metaphysics, especially in Being and Nothingness, in relation to the metaphysical problem developed in the work: the emerging of nothing in being. Finally, it aims through this analysis, to understand the status of finitude in the same work.
\end{abstract}

Keywords: Metaphysics. Being. Foundation. Finitude. Contingence.

\section{I}

A Conclusão de O Ser e o Nada possui um caráter muito peculiar que leva à necessidade de revisão de certas questões que nem sempre são demarcadas no decorrer da obra. Primeiramente, ela já sublinha outro direcionamento, qual seja, de que não são apenas conclusões,

* Mestre e Doutorando em Filosofia (UFPR). Professor temporário (UNICENTRO). < mso-01@ hotmail.com>.

** Pós-doutor em Filosofia (USP). Professor associado (UFPR). <luizdamon@yahoo.com.br>. 
não há apenas uma retomada da ontologia: são, além de tudo, esboços metafísicos. Além disso, é nela que Sartre responde a questão formulada na Introdução: "qual o sentido do ser, na medida em que compreende em si essas duas regiões radicalmente cindidas?"(EN, p. 40). Se a resposta à questão principal da obra já acentua um possível aspecto metafísico da mesma, então se faz necessário uma revisão nela, sob a ótica da Conclusão, para melhor compreender o sentido desse apontamento metafísico e em que medida ele redimensiona a ideia de finitude. Isto é, o que leva em uma obra que, a princípio, rejeita qualquer postulado metafísico, na medida em que trata radicalmente da finitude humana, a encontrar-se com a metafísica na síntese de seus resultados, e que implicações isso traz à compreensão da finitude?

Tal releitura será norteada por uma questão específica. Em O Ser e o nada, a ontologia pela fenomenologia constata que o nada vem do ser. Mas a Conclusão aponta um problema: essa aparição do nada no cerne do ser escapa à ontologia. Isso porque a ontologia trata de descrever as estruturas de um ser, ela não vai além daquilo que o fenômeno de ser revela. Mas se fundamentalmente o que entra em questão é o sentido da união das duas regiões do ser, então já não se trata apenas de descrever as estruturas segundo as quais se constitui o fenômeno, mas de compreender o sentido do ser como "acontecimento absoluto que advém ao ser" (EN, p. 667). E aqui surge uma notável diferença, segundo Sartre, a natureza dessa interrogação não é ontológica, mas "metafísica". Trata-se, segundo ele, de explicar um acontecimento: "nós chamamos de metafísico, com efeito, o estudo dos processos individuais que deram origem a esse mundo como totalidade concreta e singular" (EN, p. 667); ou ainda, interroga-se sobre a "existência do existente" (EN, p. 337). Por isso, ela é diferente da ontologia, que nada mais busca que a "explicitação da estrutura do existente tomado como totalidade" (EN, p. 337). Assim, o estudo metafísico pode ser condensado na seguinte questão: "por que o para-si surge a partir do ser"? Esta questão é pressuposta em alguns momentos críticos da obra, onde a ontologia esbarra em seus limites e o sentido de seus postulados mostra-se sujeito a uma dimensão metafísica, qual seja, a questão do fundamento. É por sobre ela que a filosofia de Sartre oscila entre a metafísica e a ontologia. A pressuposição deste trabalho é que tal movimento pode denotar uma ideia de finitude que escape à proposta sartriana, e que, por fim, coloque em questão algumas de suas assertivas mais fundamentais.

Deste modo, o objetivo deste trabalho é analisar o estatuto da metafísica em O Ser e o Nada, de modo a determinar como ele circunscreve a finitude. Num primeiro momento, procurar-se-á compreender como a metafísica pode estar presente no corpo da obra, e não apenas na 
conclusão, seja pelos elementos que levam a interrogação metafísica, seja pela discussão que Sartre trava, ainda que indiretamente, com a tradição Metafísica. ${ }^{1}$ Por conseguinte, postos em tela os elementos que ressaltam o caráter problemático da metafísica na obra, será exposta uma discussão sobre o seu real estatuto, procurando compreender como essa questão foi recebida por diversos comentadores, de modo a encontrar uma forma adequada de compreendê-la na obra de Sartre. Por fim, será estabelecido como isso circunscreve a ideia de finitude em O Ser e o Nada e um breve apontamento das suas implicações.

\section{II}

As chamadas questões metafísicas não são exclusivas da Conclusão de O Ser e o Nada, elas aparecem em diversas partes da obra, como, por exemplo, na análise do tempo objetivo. Ali, Sartre constata que, de fato, "algo vem do ser" (EN, p. 242), são as abolições e aparições de diversos istos. Além disso, uma vez que toda experiência revela que "só há ser" (EN, p. 253), Sartre é obrigado a conceber o em-si como fundamento dessas abolições e aparições. Todavia, tanto uma como a outra só podem ser exteriores ao em-si, pois este tendo como lei de ser o princípio de identidade não põe-se a ser, ou seja, não podem ser "aventuras do ser-que-aparece" (aventures de l'être apparaissant). Do mesmo modo, o "há" só vem ao ser pela nadificação, isso significa que se há aparições e abolições, elas são sobre um mundo, por isso eles serão, para Sartre, fenômenos ambíguos, pois eles só vêm ao mundo retrospectivamente pelo para-si, deste modo, eles também seriam nada, não-ser-ainda (n'êtrepas-encore), e não-ser-mais (n'être-plus). Por conta desta ambiguidade, Sartre desvia o problema.

Algo parecido acontece com o problema do Outro. Depois de descrever as estruturas essenciais do para-outro, Sartre é tentado a levantar uma questão metafísica: "por que há outros"? (EN, p. 336). Mas, neste ponto, há, agora, um posicionamento ante essa questão enquanto metafísica, e ainda, de certa forma, decorrente deste posicionamento,

\footnotetext{
${ }^{1}$ Compreende-se, aqui, como Metafísica, as soluções infinitistas dadas ao problema da finitude, como se pode observar, ainda que numa matriz heideggeriana, o comentário de Loparic ( $\mathrm{p}$. 9): "O infinitismo é o principio organizador da metafísica ocidental. Na ontologia, buscamse causas e verdades; na ética máximas e regras, que sejam, ao mesmo tempo, primeiras e vigorem incondicionalmente, que sejam infinitas. Quais são as esperanças depositadas na infinitude do fundamento? As de encontrar um solo sobre o qual seria possível, pelo menos em tese, assentar uma vida humana plenificada, eterna e integrada numa totalidade cósmica social, Em outras palavras, visa-se achar um antídoto universal para a falta, a transitoriedade e a particularidade, três elementos constituintes da finitude humana, todos assinalados pela dor".
} 
uma desconfiança sobre a própria possibilidade deste tipo de questão. Dada a absoluta contingência do existente fica excluso qualquer lastro de necessidade que ele possa ter. Nesse sentido, a resposta metafísica só pode ser negativa, ela simplesmente conclui pela intuição direta desta contingência com um "é isto" (cela est), "é assim" (c'est ainsi). A desconfiança sobre a possibilidade da questão metafísica do outro é posta porque embora seja possível conceber a pluralidade das consciências como uma síntese e não como uma coleção, a totalidade dessa síntese é inconcebível. Isso porque não há a possibilidade de "tomar um ponto de vista sobre a totalidade" (EN, p. 341), isto é, vê-la pelo lado de fora (dehors), justamente porque não há lado de fora da totalidade e muito menos como se colocar nele, pois,caso fosse possível, ela já não seria mais totalidade, mas apenas um objeto sem status ontológico maior; portanto, a questão é desprovida de sentido.

Postos tais problemas é de questionar-se por que Sartre insistiria na Conclusão em esboçar uma metafísica, uma vez que o ser como contingência absoluta parece fechar todas as portas para tal empreendimento. Além disso, a própria pergunta metafísica "por que há ser?" carece de sentido, pois a resposta é encontrada já no terreno da ontologia: “'há' ser porque o para-si é tal que faz com que haja ser" (EN, p. 667). Mas, ainda que a questão não faça sentido, é preciso lembrar que, na Conclusão, o que está em jogo não é a origem do ser. Só há ser e o ser é incriado. No entanto, algo ocorre (arrive) ao ser. Esta ocorrência é premeditada antes mesmo da Conclusão. No final da segunda parte de O Ser e o Nada, O Conhecimento, Sartre já esboçava aquilo que será condensadona Conclusão:

Nós poderemos, no final deste livro, considerar esta articulação do para-si com relação ao em-si como um esboço perpetuamente móvel de uma quase-totalidade que nós poderemos chamar Ser. Do ponto de vista desta totalidade, o surgimento do para-si não é somente o acontecimento absoluto para o para-si, é também algo que ocorre (arrive) ao em-si, a única aventura possível ao em-si [...] Mas então, na quase-totalidade do Ser, a afirmação ocorre ao em-si: a aventura do em-si é ser afirmado (EN, p. 253).

Se, nesse momento, Sartre conclui que a ocorrência no ser seja como um jogo de afirmação e negação entre o para-si e o em-si, cujo resultado termina com a determinação do mundo, ao mesmo tempo ele dá indícios de respostas às questões metafísicas. Isso porque a relação aí já é premeditada também no âmbito metafísico, pois a relação aparece como esboço perpetuamente móvel de uma quase-totalidade que nós poderemos chamar Ser, tarefa que Sartre já alerta deixar para a Conclusão. Deste modo, ainda que ele inicie a Conclusão tratando da ocorrência como 
determinação do mundo, é preciso levar em conta que ela ultrapassa esse sentido, na medida em que não é só mais ocorrência do mundo, mas ocorrência do ser, isto é, do surgimento do para-si no em-si, isto que Sartre chama de acontecimento absoluto. Este não diz respeito somente ao para-si, mas também ao em-si, por isso ele será apreendido como sendo do ponto de vista da totalidade. Ainda que a ontologia descreva as estruturas do existente, enquanto totalidade, ela não consegue ir além da aparição do nada no ser, ou seja, ela toma a relação como dada. De fato, é somente na Conclusão que esse adotar o ponto de vista da totalidade é reexaminado para demonstrar que não há uma contradição quando, na análise do Outro, diz-se que não se pode ter um ponto de vista da totalidade, sendo que anteriormente já havia sido feita a promessa de esboçá-la no final na obra.

Mas, se nós não podemos 'tomar o ponto de vista sobre a totalidade' é que o outro, por princípio se nega a ser eu como eu me nego a ser ele. É a reciprocidade da relação que me impede sempre de aprendê-lo em sua integridade. Ao contrário, no caso da negação interna para-si-emsi, a relação não é recíproca, e eu sou ao mesmo tempo um dos termos da relação e a própria relação. Eu apreendo o ser, eu sou apreensão do ser, eu não sou senão apreensão do ser; e o ser que eu apreendo não se põe contra mim para apreender-me por sua vez: ${ }^{2}$ ele é o que é apreendido. Simplesmente seu ser não coincide de modo algum com seu ser-apreendido. Em certo sentido, portanto, eu posso levantar a questão da totalidade (EN, p. 672).

O fato de considerar-se o ser como não coincidindo com seu serapreendido significa dizer que o ser é independente de sua fenomenalidade. Umas das coisas que Sartre assinala em toda a obra é que há certa dependência da consciência com o ser do transcendente, pois cada um considerado à parte não passaria de um abstrato. Mas eis que há um problema: embora esses seres existam sempre como que comprometidos nessa relação, não há uma reciprocidade da relação entre eles, uma vez que o para-si é o próprio termo da relação: "o para-si e o em-si estão reunidos por uma ligação sintética que é o próprio para-si" (EN, p. 665). A consciência é outro que não o em-si, mas o em-si não é outro que não a consciência; significa que "o em-si não necessita do para-si para ser: a 'paixão' do para-si faz somente que haja em-si. O fenômeno do em-si, sem a consciência, é abstrato, mas não seu ser" (EN, p. 670).

$\mathrm{Na}$ Introdução de O Ser e o Nada, Sartre postula o ser como o fundamento do fenômeno, pois é a condição de seu desvelamento, já

\footnotetext{
${ }^{2}$ Paulo Perdigão, em sua tradução de O Ser e o Nada,pela editora Vozes, sugere nessa parte
} uma possível errata, e interpreta mon tour por sua vez. Adere-se aqui a sua interpretação. 
que a nadificação só pode ocorrer sob um fundo de ser. Mas dizer que o ser é contingente e independente de sua fenomenalidade não responde como ele pode ser transfenomenal, a menos que ele tivesse apenas o sentido de independente do fenômeno, o que não é o caso, uma vez que ele também é fundamento do fenômeno. Nesse sentido, a questão do surgimento do para-si significa também a do sentido do ser, isto é, do ser como fundamento, ocorrência e totalidade. Sartre não aborda essa questão somente na Conclusão. Nas análises feitas na segunda parte da obra, no estudo sobre a estrutura interna do para-si, já há indícios para a formulação de respostas que permitam compreender melhor essa relação. Se o ser é incriado, apenas é, significa que também não pode criar ser, nem pôr-se a ser. Entretanto, na segunda parte, vê-se que há um ato que vem do ser pelo próprio ser: o nada; que "é a possibilidade própria do ser e sua única possibilidade" (EN, p. 115). Se a consciência enquanto nada vem do ser, mas o ser é contingente, significa que algo ocorre no ser mediante sua contingência fundamental. Sartre aborda essa questão com maior ênfase quando estuda nas Estruturas imediatas do para-si a facticidade. Mas é porque, ali, Sartre está mais preocupado com aquilo que constitui a consciência em seu âmago que o problema do ato ontológico não é visto ainda como um problema metafísico, isso porque, como pensa Husson, ${ }^{3}$ é a partir da determinação do ato ontológico que se instala a dimensão da facticidade, a descoberta do para-si de que "há algo do qual ele não é fundamento: sua presença ao mundo" (EN, p. 115).

A apreensão deste ato é um movimento análogo à descoberta de Descartes da imperfeição do homem através da ideia de perfeição, presente, segundo Sartre, no fundo de todo cogito. ${ }^{4}$ Mas, no caso de Sartre, a segunda prova da existência de Deus é substituída pela captação do para-si de sua facticidade, pois, segundo ele, restaria do argumento cartesiano desprovido de sua terminação escolástica apenas o sentido de

\footnotetext{
3 “É a partir desta determinação que é introduzida a dimensão da facticidade. Com efeito, estamos aqui na ordem de um fato, mas de um fato que não introduzido a partir da dimensão do ser-no-mundo e em relação ao transcendente (l'étant), mas que é introduzido com relação ao ser puro, e, mais exatamente, ao ato puro de ser" [...] (HUSSON p. 136).

4 Embora não tematizado diretamente, e sendo completado só quando Sartre estudar a questão da falta, essa característica de imperfeição remete à noção clássica do imperfeito, como bem observou Silva (p. 177): "Em Sartre no entanto, esse nada de que a realidade humana é "feita" não está nela como elemento de sua composição, porque não existe a plenitude divina e criadora como a contrapartida e sustentáculo desse nada. Por isso, a realidade humana não apenas comporta uma falta, como um vazio parcial, como denota a noção clássica de imperfeição, mas é falta, isto é, a falta a constitui". Assim, embora diferente do modo como em Descartes o homem se descobre imperfeito - através da ideia de perfeição, em Sartre o homem se descobre como contingente, ou mergulhado na facticidade, na medida em que se descobre que não é seu próprio fundamento. Mas essa descoberta não dispensa, ao menos como ideal, uma forma de compreensão do que seria o fundamento. Daí, como será demonstrado a frente, a facticidade reenvia a questão do em-si-para-si.
} 
que "o ser que possui em si a ideia de perfeição não pode ser seu próprio fundamento, senão ele se produziria em conformidade a esta ideia" (EN, p. 116). Esse desnível entre ser o que se é e ser o que se poderia ser é um apontamento da contingência do para-si, ou seja, que ele não encontra em si mesmo a explicação de seu ser, e nem a recebe de outro ser.

É neste ponto da obra que se inicia com maior ênfase o que se poderia chamar de contrapé do problema da contingência, ${ }^{5}$ e que, por sua vez, parece remeter a uma outra oposição além da oposição entre em-si e para-si, e que talvez seja até mais fundamental: a relação entre o perfeito e o imperfeito, o possível e o necessário, a contingência e a necessidade ou fundamento, e, principalmente, a do finito e do infinito. Embora todos esses termos não sejam análogos, todos os anteriores remetem aos últimos. E diz-se aqui mais fundamental porque aquilo que a princípio deveria explicar a facticidade explicará também como pode haver relação entre um ser que é distância a si e um ser que não guarda a menor distância em seu ser; explicará ainda como pode ocorrer a nadificação do ser e porque essa nadificação é constante, enfim, explicará a grande dependência da fenomenologia para com a ontologia: o porquê de o caráter de fenômeno vir ao ser.

Se o nada advém ao ser, e se o ser não pode criar nada, então significa que a ocorrência no ser, como nadificação do ser, é uma modificação de seu próprio ser. Sartre entende essa ocorrência como um esforço (effort) de fundamentação do em-si, uma tentativa (tentative) de eliminar (lever) sua contingência. Convém, antes de tudo, salientar que os termos esforço, tentativa, eliminar, e, sobretudo, fundamento, são termos bastante caros à ontologia, já que, deixando de lado o sentido metafórico que possa haver em alguns, todos reenviam a um sentido metafísico. Se esta afirmação tem um tom apelativo, já que, em nenhum momento, Sartre considera-os

\footnotetext{
${ }_{5}$ Como demonstrou Moutinho ( p. 22), a passagem da psicologia à fenomenologia pura em Sartre dá-se devido à noção de contingência, que, pelo fato de Husserl adotar a tese idealista de constituição do ser, escaparia ao mesmo. Desse modo, tal conceito seria um dos principais elementos da filosofia de Sartre. Destacou-se desde o início a contingência do ser. No entanto, fala-se aqui em contrapé do problema da contingência porque quando Sartre vai explicar a questão da facticidade, e mesmo depois do surgimento do para-si, ele vale-se não de uma descrição pura como feita inicialmente, e ainda que provisória, no caso do em-si; o para-si será compreendido como contingente com relação ao ideal de fundamento, isto é, ao emsi-para-si: "[...] no caso da Causa sui, é o ser contingente que por intermédio da falta busca se fundar" (CM, p. 160). Fala-se aqui em contrapé, porque se acredita que haja algumas implicações nessa mudança de formulação, isto é, a postulação de um ideal de fundamento acarreta alguns problemas. Um desses problemas, como já observado por Souza ( p.84 - nota 59) seria uma possível queda no idealismo: "Talvez esta seja a origem do idealismo sartriano, visto que essa totalidade [em-si-para-si] é que vai, em última instância, determinar todos os fenômenos particulares; até mesmo a relação do Para-si com o Em-si da facticidade" (grifos nossos).
} 
como tais, basta, para que isso seja deixado de lado, tentar entender onde eles podem encaixar-se enquanto conceitos, não só na ontologia, mas em toda a filosofia de Sartre. Todos esses termos pressupõem uma finalidade: todo esforço e tentativa visam a algo, e toda eliminação pressupõe uma finalidade, uma estado o qual se objetiva, sobretudo uma mudança: tentar eliminar a contingência, isto é, fundamentar-se.

Mas em que consiste o ato de fundamentação, isto é, quando se pode dizer que um ser é seu próprio fundamento? Em que sentido, de fato, Sartre emprega a palavra fundamento? "Para fundamentar seu próprio ser, é necessário existir a distância de si e isso implicaria certa nadificação tanto do ser fundamentado como do ser que fundamenta, uma dualidade que seria unidade: recairíamos no caso do para-si" (EN, p. 116). Nesta passagem já se antecipa aquilo que será mais bem definido por Sartre à frente, em O Ser e o Nada, e que reenvia de certo modo à tradição Metafísica, como, por exemplo, vê-se em Hegel, no $\$ 121$ da Ciência da Lógica, que o fundamento "é fundamento somente enquanto é fundamento de Algo, de um Outro" (Hegel, p. 238). O ser que é identidade pura consigo mesmo não fundamenta nada, ele é absoluta contingência, daí o sentido do ser idêntico como em-si e este como contingente. Nesse sentido, toda tentativa de fundamentação do ser acaba recaindo sempre sobre o modo de ser do para-si, esse ser que é distância a si, e que, portanto, se autofundamenta enquanto é causa de sua própria maneira de ser. Nele, é seu ser que sustenta suas próprias possibilidades, sua essência é determinada por sua existência. Mas esta maneira de ser, que se dá sob a facticidade - por que há consciência disto e não daquilo? - reenvia a sua contingência originária - por que há consciência e não apenas o em-si? É contingente o fato de que haja consciência e não apenas o em-si ao infinito, mas se há consciência, esta tem que ser fáctica, ser sob o ser (ainda que contingente), ser de tal modo, senão seria puro nada. Isso significa, para Sartre, que o para-si é fundamento apenas de seu nada, mas não de seu ser, isto é, apenas na medida em que se determina livremente como não sendo o ser. Enquanto nadificação de si, ele não só não fundamenta o seu ser, como assume essa total contingência. Assim, mesmo sem ser o fundamento de seu ser, o para-si nadifica-se sempre sobre um fundo de ser, ou na expressão de Sartre, com uma lembrança do ser (souvenir d'être), e esta lembrança é a facticidade:

Assim o para-si é sustentado por uma perpétua contingência, que ele retoma por sua conta e assimila sem jamais poder suprimi-la. Esta contingência perpetuamente evanescente do em-si que infesta (hante) o para-si e o une ao ser-em-si sem jamais se deixar apreender, é o que chamaremos a facticidade do para-si. É esta facticidade que permite 
dizer que ele é, que ele existe, ainda que nós não possamos jamais realizá-la ${ }^{6}$ (la réaliser) e que a apreenderemos sempre através do para-si (EN, p. 119).

Deste modo, a facticidade é uma maneira de apreender esse desnível do ser que não é seu próprio fundamento, e mais: se há um esforço do em-si em suprimir sua contingência, ela reenvia ao fracasso dessa tentativa. A argumentação consiste novamente numa discussão ainda que não tão explícita, já que nesta altura da obra o que se busca definir são as estruturas imediatas da consciência, e isso por um viés ontológico, - na retomada e crítica, que remonta à tradição Metafísica, mais precisamente a Leibniz, de que a necessidade do ser não pode ser derivada de sua possibilidade. O nada é a única possibilidade do ser, mas essa possibilidade é uma tentativa de fundamentação de seu ser, fundamentação que permanece frustrada. Mas como não se pode definir o necessário a partir do possível, se Leibniz, de acordo com Sartre, já postulava isso (o necessário é um ser cuja possibilidade pressupõe existência)? É que, para Sartre, Leibniz permanece do ponto de vista do conhecimento e não do ser e, portanto, ele assinala apenas a passagem da ignorância ao conhecimento. ${ }^{7}$ Deste modo, Sartre entenderá que o possível só pode ser concebido devidamente sobre dois modos: ou como estrutura ontológica do real, e nesse caso interna ao próprio ser, ou como uma indicação subjetiva, a qual é exterior ao ser. Nesta última, a possibilidade só é possibilidade aos olhos de uma testemunha: é possível que Pedro esteja ou não no bar, mas o olhar que confirma esta possibilidade é um olhar exterior, pois este possível dá-se em presença do mundo. Mas a possibilidade que Pedro tem ou não de ir ao bar é parte de seu próprio ser e encontra nesse ser seu próprio fundamento, portanto não faz sentido derivar a necessidade de ir de sua possibilidade. É o que expressa a conclusão contra Leibniz: "Deus, se existe, é contingente" (EN, p.117). Isso significa que se o nada é a possibilidade única e própria do ser, o ser não consegue derivar sua necessidade de tal possibilidade, ou seja, ainda permanece contingente:

[...] o em-si não pode fundamentar-se sem introduzir o si, ou remissão reflexiva e nadificante, na identidade absoluta de seu ser, e, por conseguinte, sem degradar-se em para-si. Portanto, o para-si corresponde a uma destruição descompressora do em-si, e o em-si se nadifica e se absorve nessa tentativa de se fundamentar (EN, p. 120).

${ }_{6}^{6}$ Ela [a facticidade] é apenas uma indicação que eu dou a mim mesmo do ser que eu devo alcanÇar (rejoindre) para ser o que sou. É impossível captá-la em sua nudez bruta [...] (EN, p. 119).

7 Segundo Coorebyter (nota 89, p. 215) a tese de Leibniz aqui é "articulada sob a tese espinozista do possível como efeito de um conhecimento imperfeito". 
É porque o para-si encontra-se sempre mergulhado na facticidade que ele não deixa de ser sempre relação ao em-si. É a partir dessa necessidade de ser nadificação do ser sem ser fundamento do ser, que essa estrutura do real, em-si e para-si, serão como articulações daquilo que Sartre chama de quase-totalidade ou Ser. Isso já demonstra de antemão que a totalidade não pertence ao ser, embora ele adquira sua realidade mais forte desta sombra. Não é uma totalidade porque a relação entre em-si e para-si não é recíproca: para que fosse considerada uma totalidade seria necessário "que a diversidade de suas estruturas fosse mantida em uma síntese unitária, de tal maneira que cada uma delas considerada a parte, não passe de um abstrato" (EN, p. 670). Nesse caso, não se poderia chamar totalidade porque como foi visto o em-si considerado a parte não é abstrato. Mas é sob a égide desta quase-totalidade que se deve compreender a relação entre em-si e para-si, e aliás, é só por ela que se pode conceber como dois absolutos mantêm, apesar de sua não-reciprocidade, o que se poderia chamar de relação. Poder-se-ia dizer, de modo mais direto, que essa relação é a própria ocorrência no ser como modo pelo qual ele busca fundamentar-se. Ou seja, já se encontra na parte das Estruturas Imediatas aquilo que Sartre virá a definir no capítulo seguinte, $A$ Transcendência, a saber, que a relação é, antes que fenômeno, nexo de ser:

O em-si é para perder-se em para-si. Em uma palavra, o ser é e não pode senão ser. Mas a possibilidade própria do ser - essa que se revela no ato nadificador - é o de ser fundamento de si pelo ato sacrifical que o nadifica. O para-si é o em-si se perdendo como em-si para se fundar como consciência. Assim a consciência obtém de si própria seu ser-consciente e não remete senão a si mesma enquanto é sua própria nadificação, mas o que se nadifica ( $s$ 'anéantit) em consciência, sem que possa ser dito fundamento da consciência, é o em-si contingente. $\mathrm{O}$ em-si não pode fundamentar nada; se ele se fundamenta é dando a si mesmo a modificação do para-si. Ele é fundamento dele mesmo enquanto já não é mais (n'est dejá plus) em-si. E nós encontramos aqui a origem de todo fundamento. Se o ser-em-si não pode ser nem seu próprio fundamento nem dos outros seres, o fundamento em geral vem ao mundo pelo para-si. Não apenas o para-si, como em-si nadificado, fundamenta a si mesmo, mas aparece com ele, pela primeira vez, o fundamento (EN, p. 118).

Assim, compreende-se que o em-si não consegue fundamentar seu ser, consegue apenas fundamentar seu nada, conferindo a si mesmo a modificação em para-si. E esse para-si porque é distância a si é fundamento de seu nada, e por isso o fundamento só vem ao mundo pelo para-si. Mas o para-si não é fundamento de seu ser, permanecendo na facticidade. Portanto, pode-se dizer que é essa dinâmica de fundamentação que 
caracteriza a relação originária do em-si com o para-si: "o ato de causação pelo qual Deus é causa sui é um ato nadificante como toda retomada de si por si, na exata medida em que a relação primeira de necessidade é um retorno a si, uma reflexividade" (EN, p. 117). Isso quer dizer que somente sob o ponto de vista da causa de si é que se pode compreender esse esforço do em-si em fundamentar-se, e esse esforço como relação originaria entre em-si e para-si. ${ }^{8}$ Nesse sentido, é o conceito de causa de si, que já está por trás do de facticidade, que substitui o da ideia de perfeição como no caso de Descartes: é por ele que Sartre explica o desnível ontológico entre o ser que é seu próprio fundamento (apenas ideal, por ser impossível) e o ser carente de fundamento (o ser real). Assim, a contingência já não é descrita puramente nela mesma, mas em contraposição ao conceito de fundamento, ainda que este seja apenas ideal, e não encontre lugar real no ser. Mas esse salto ao fundamento, o surgimento do nada no ser, faz com que tudo se passe como devesse haver dois fundamentos, um do ser e outro do nada, ou melhor, um único fundamento que englobasse os dois. No entanto, a própria estrutura de um deles corresponde à estrutura do fundamento, de modo que, como foi visto, o fundamento só pode ser como para-si, como distância e, portanto, reflexividade, o que significa dizer que a contingência do ser é eterna.

Poder-se-ia concluir, assim como Husson, que a noção de causa de si, o ato ontológico, aparece como certo recurso para explicar a noção de facticidade. Mas, na verdade, esta noção vai mais longe. A noção de ens causa sui torna-se o ponto arquimediano da filosofia de Sartre, pois tudo passa a ser explicado a partir dela e recorre a ela, seja a relação das duas regiões de ser, seja a fenomenalidade do real, e mesmo o fato da contingência. Essa dinâmica de fundamentação passa a ser a estrutura do real, tanto que ela estende-se ainda em mais um ek-stases da realidade (alémda presença a si ela estende-se a reflexão), fazendo que as dimensões mais essenciais do real sejam explicitadas segundo sua estrutura.

Entretanto, é preciso observar que a análise aqui feita do ato ontológico, bem como a indicação da presença a si e da reflexão como condicionadas por essa estrutura de fundamentação, não é um exame metafísico que Sartre realiza sobre o surgimento do para-si. Esses dados são obtidos pela ontologia, e Sartre é claro em frisar isso na obra. Todavia,

\footnotetext{
${ }_{8}^{8}$ Sobre este aspecto, é muito valioso o comentário de Silva (p.178) "A realidade do negativo consiste justamente nesse recobrimento paradoxal entre ser a ausência de ser. É isso o que se quer dizer quando se afirma que a realidade-humana traz o nada no seu ser. A existência é dor, angústia, inquietação e instabilidade porque o para-si, sendo originariamente não o que é, mas o que lhe falta para ser, transcende-se constantemente na direção do ser como totalidade, sem nunca alcançá-lo. Nesse sentido, para-si poderia significar para-ser, movimento que tende a constituir o si como ser, tarefa jamais completada" ( negritos nossos).
} 
as referências a Descartes, Espinosa, Leibniz e Hegel lançam as análises de Sartre dentro de uma discussão, que, se não é metafísica, sugere ao menos um debate com a Metafísica.

Posto isso, é de perguntar-se: O que significa essa discussão com a Metafísica clássica e a retomada da noção de ens causa sui? Qual o real estatuto da Metafísica em Sartre? E que será do problema do fundamento? Será ele metafísico ou ontológico? Diante disso, como fica a dimensão da finitude?

\section{III}

Se, por um lado, encontra-se uma discussão com a Metafísica, por outro, Sartre não evita a tentativa de definir o papel de uma metafísica perante sua ontologia. Em um primeiro momento,poder-se-ia pensar o que caracteriza a ontologia e a metafísica. De imediato, uma resposta seria a diferenciação de seus métodos. O método da ontologia é o fenomenológico. Como ela descreve a estrutura do real, do em-si e do para-si, seu caráter é apodítico e estrutural, pois ela não vai além daquilo que é dado na intuição. Já a metafísica possui um caráter genético, ela trabalha com a origem do para-si no em-si e o sentido dessa aparição, que, como nas análises precedentes, basicamente consiste na determinação da "gênese de Deus". Deste modo, haveria segundo Prado Jr. (2006, p. 33) "uma descontinuidade entre as duas perspectivas [...] a metafísica aparece como regulação, na sua oposição à constituição ontológica". Sartre não é claro quanto a seu método, apenas assegura que não pode ser um "sobrevir histórico do ser", já que a temporalidade surge pelo para-si. Posto isso, é de perguntar-se o que Sartre pretende de fato com essa proposta da metafísica em O Ser e o Nada, isto é, qual a real função da Conclusão, e o que será da questão do surgimento do para-si.

As escassas passagens na obra, e mesmo a discussão na Conclusão, tornam difícil não só de estabelecer-se uma resposta, mas mesmo determinar seu alcance e validade, o que proporciona, assim, diversas possibilidades de interpretação. Uma das interpretações mais correntes é de que, na verdade, Sartre pretende mostrar a desnecessidade e mesmo impossibilidade de um discurso seguro da metafísica, como pensa Gary Cox:

Sartre, entretanto, não rejeita somente esta fraca tentativa de justificar a emergência do para-si, ele rejeita, em princípio, todas as tentativas de justificar a emergência do para-si. [...] de acordo com Sartre, a irrupção do para-si do ser tem que ser aceita como axiomática, assim como o ser do ser será aceito como axiomático [...] Sartre, o existencialista, certamente não gostaria de um discurso metafísico sobre a emergência da consciência [...] (COX, p. 26 e 27). 
Essa investida contra a Metafísica seria também afirmada por Jeanson (p. 158), uma vez proposta por Sartre a absoluta contingência do ser: "O em-si de Sartre recusa toda consideração teológica ou metafísica; ele é apenas um dos polos de uma descrição, polo cuja fixação em conceitos é rigorosamente implicado pela significação mesma dessa descrição". Assim como foi observado na questão do problema metafísico quando se analisou-o conforme posto no exame do ser-para-outro, a contingência do ser permitiria somente uma fenomenologia, isto é, a descrição daquilo que se apresenta à intuição e, justamente por tal contingência, qualquer consideração metafísica do mesmo estaria bloqueada desde o início. Assim, segundo Jeanson, a fenomenologia, ainda que como ontologia, não visaria à descrição do Ser, mas sim da liberdade:

É porque nos definimos O Ser e o Nada como uma ontologia da liberdade. Pois esta obra, no fundo, não estuda o Ser - como o faria uma metafísica, mas a livre atitude da realidade humana em relação a todo 'em-si' suscetível de fascinar sua liberdade, da tentativa de se prender em si mesma (JEANSON, p. 254).

O desprendimento de tal estudo da liberdade perante um estudo metafísico dar-se-ia devido o fato de o Ser não ser mais algo transcendente à realidade e, portanto, algo abstrato, mas por definir-se como particular, isto é, orientando sempre para a prática: "Nós diremos, de boa vontade, que a metafísica é uma teoria gratuita, uma teoria pela teoria, entretanto, uma ontologia, tal como na definição de Sartre, é uma teoria oriunda de uma descrição psicológica concreta, e orientada rumo à prática" (JEANSON, p. 146). Assim, o primado da prática e a contingência do ser fariam da fenomenologia de Sartre uma pura fenomenologia, isto é, uma filosofia que não somente rejeita uma metafísica, mas que não necessita dela para sustentar-se.

Deste modo, se levar-se em conta as considerações das análises precedentes, tais como o fato da impossibilidade da questão do outro do ponto de vista metafísico, do mesmo modo sobre a questão das abolições a aparições dos istos na realidade; e, ainda, a impossibilidade de derivação do necessário a partir do possível, e principalmente, a respeito do fundamento, a impossibilidade de uma fundamentação absoluta, parece que realmente o que Sartre pretende é demonstrar que a metafísica não só é impossível, como, neste período da história da filosofia, ela tornou-se inviável. Nesse caso, O Ser e o Nada deveria ser considerado um ensaio antimetafísico, e a Conclusão teria apenas uma função negativa, que, atrelada a negação das teses metafísicas já discutidas no corpo do texto da obra, mostraria que nada pode validar hipóteses metafísicas. 
Todavia, a questão é mais complexa. A forte temática da liberdade e dela como sendo essencialmente tratada no terreno da práxis e do mundo, tal como ele se apresenta à consciência, direciona inicialmente a considerações como as de Cox e Jeanson. Mas, mesmo perante tais considerações, encontram-se outros posicionamentos sobre esta questão, e que, por pressuporem outro ponto de vista, convém analisá-los. Antes disso, talvez seja válido levantar algumas questões que permitiriam a possibilidade de adotarem-se estes outros posicionamentos. Primeiramente, se Sartre diz que a metafísica deverá formular hipóteses é de questionar-se o que permitirá a ela formular tais hipóteses, isto é, seu método, bem como o que as validaria. Se a observação de Cox e Jeanson fosse seguida ao extremo, dever-se-ia concluir que simplesmente a formulação de hipóteses é impossível, já que o único acesso ao ser do fenômeno é pelo fenômeno de ser, ou seja, ainda que o ser seja independente da sua fenomenalidade, a única via de acesso ao ser é pelo fenômeno de ser. Nesse sentido, é possível afirmar que há uma dependência da ontologia para com a fenomenologia. Mas isso não ocorre no caso da metafísica, já que trata de explicar um acontecimento e não descrever as estruturas de um ser. Sartre poderia simplesmente considerar a metafísica como uma doutrina limitativa da ontologia, isto é, questões de ordem metafísica nada mais fazem que determinar os alcances da ontologia, a região que escapa à fenomenologia. Entretanto, pelo contrário, ele sugere que o que tornaria as hipóteses metafísicas passíveis de serem aceitas, o que lhes constituiria sua validade, seria o fato de por elas ter-se a possibilidade de "unificar os dados da ontologia", sendo que, para formular tais hipóteses, ela poderia valer-se da própria ontologia para obter "informações" que lhe serviriam de base para tal empreendimento.

Seriam duas as informações principais enumeradas por Sartre. Primeiramente, a de que "todo processo de fundamentação de si é ruptura do ser-idêntico do em-si, distanciamento do ser com relação a si mesmo, e aparição da presença a si ou consciência. É somente se fazendo para-si que o ser poderia aspirar a ser causa de si" (EN, p. 668). A partir disso, Sartre formula a segunda informação: "o para-si é efetivamente projeto perpétuo de fundamentar a si mesmo enquanto ser e perpétuo fracasso desse projeto" (EN, p. 668). Se o esforço do em-si resulta no para-si, há como um segundo esforço de fundamentação, só que agora por parte do para-si, que, primeiramente, perde-se no em-si, e depois o redobramento nesse projeto que culmina apenas na aparição do para-si para ele mesmo (a reflexão). É como se o em-si se nadificasse em para-si, com vista à causa de si, e o para-si, por sua intencionalidade, buscasse o em-si também com vistas à causa de si, mas em ambas as tentativas o fracasso é o único resultado. 
Essas são as únicas indicações a respeito do método e validade das hipóteses metafísicas. Ainda que, como observa Prado Jr, haja uma descontinuidade entre ontologia e metafísica, é certo que sua relação permanece ambígua, já que, ao que tudo indica, nada além desses dados da ontologia podem ser utilizados pela metafísica. Todavia, como Sartre mesmo assegura que os acontecimentos que a metafísica estuda são os "desse mundo" (ce monde-ci), resulta que ela não faz especulações sobre uma realidade inteligível, já que ele assevera que a região da causa de si, ainda que puramente ideal, é elucidada, primeiramente, pela ontologia. Por isso, nesse sentido, para Sartre, "a metafísica está para a ontologia, como a história está para a sociologia". É certo que a metafísica não pode ser constituída na perspectiva de um sobrevir histórico. Entretanto, Sartre assevera: "a metafísica não deve renunciar a tentar determinar a natureza e o sentido desse processo ante-histórico e fonte de toda história que é a articulação da aventura individual (ou existência do em-si) com o acontecimento absoluto (ou surgimento do para-si)" (EN, p. 669). Assim sendo, Sartre, ainda que muito timidamente, veria um sentido positivo para a metafísica, e este sentido tornar-se-ia resoluto porque, no final, ele afirmaria que ela ainda poderá abordar outros problemas, como os "concernentes a ação", e mais, a partir disso "tentar uma metafísica da natureza" (EN p. 673).

Há ainda outro problema que remete a essa distinção e permite compreender a urgência da questão do surgimento do para-si, isto é, o problema metafísico: o da elucidação da noção da causa de si. Sartre afirma no final da Conclusão que as regiões do ser, o em-si e o para-si, e o ideal de causa sui são elucidados pela própria ontologia. Mas isso não deixa de levantar sérios questionamentos. Ao levantar a questão do ser todo o ideal de causa sui aparece como única forma possível de compreensão da relação entre em-si e para-si enquanto compreendidos como uma "organização sintética".

A causa de si é puramente ideal porque ela mesma é contraditória e, portanto, impossível. Ela pressupõe um ser que mantivesse a translucidez da consciência ao mesmo tempo como coincidência consigo mesmo. A causa de si torna-se contraditória porque a translucidez da consciência é mantida por sua distância a si, e dela decorre a impossibilidade de coincidência consigo mesmo, ao mesmo tempo em que o ser que possui identidade é aquele que não há a menor distância em seu ser, é plenitude absoluta. Ou seja, o para-si é excludente do em-si e vice-versa.

A ontologia pressupõe que o ideal de causa sui é a forma possível de compreender a relação sintética entre em-si e para-si, entretanto, e crê-se que esse seja um dos pontos principais no qual outros comentadores irão apoiar-se, assegura Sartre: "nada permite afirmar, no plano ontológico, que a nadificação do em-si em para-si tenha por significação, desde a 
origem do em-si e no próprio cerne do em-si, o projeto de ser causa de si" (EN, p. 668 e 669). Desta forma, ao postular a nadificação como um esforço de fundamentação, tudo se passa como se Sartre recaísse numa hipótese metafísica, uma vez que tal consideração é puramente hipotética. Isto é, a ontologia conseguiria inferir as dimensões do ser, mas seu real significado como ser todo escaparia à mesma. Daí o fato de que a metafísica viesse a unificar os dados da ontologia, o que vale dizer que, na verdade, o sentido do ser todo pertenceria à metafísica, e não à ontologia. Por isso, embora Sartre em O Ser e o Nada não se refira no capítuloas estruturas imediatas do para-si à questão metafísica, mas apenas à ontológica, a inferência do sentido do em-si e do para-si estaria recheada de especulações metafísicas. Portanto, tudo se passa como se todo O Ser e o Nada fosse uma hipótese metafísica, e talvez, a única hipótese metafísica possível.

Assim sendo, seria sob essa quase-totalidade chamada Ser que Sartre fundamentaria a constituição da fenomenalidade, já que o surgimento do para-si é a própria irrupção do mundo como fenômeno. É como o vê Barbaras, ainda que, em seu artigo,ele não discuta explicitamente essa dimensão metafísica, embora o conceito de totalidade seja da alçada da metafísica: "A correlação não é, portanto, descrita nela mesma, mas reconstituída a partir da hipótese de uma totalidade desintegrada; a relação reenvia à totalidade enquanto tal e a distância na relação à impossibilidade desta totalidade" (BARBARAS, 2005, p. 131). Essa submissão da fenomenalidade a uma dinâmica interna de uma totalidade desintegrada é totalmente contrária à intenção de Husserl, o que faz que Barbaras acuse a fenomenologia de Sartre de ser "uma fenomenologia sem fenômenos" (BARBARAS, 2005, p. 136), já que partiria das duas dimensões de ser para delas reconstituir o estatuto do fenômeno, e não a determinação das vivências da consciência. Nesse sentido, Barbaras assume que a descrição seja feita não pela correlação ela mesma, mas sobre a hipótese de uma totalidade desintegrada.Essa hipótese não está dissociada da descrição fenomenológica. Isso se confirma porque ainda que Sartre afirme na Introdução que o sentido do ser é ontológico, o sentido do sertodo só pode ser dado hipoteticamente pela metafísica:

Mas, precisamente porque nós nos colocamos do ponto de vista desse ser ideal para julgar o ser real que nós chamamos ö̉ov, nós devemos constatar que o real é um esforço abortado para alcançar a causa-de-si. Tudo se passa como se o mundo, o homem e o homem-nomundo não chegasse a realizar mais que um Deus faltado. Tudo se passa, portanto, como se o em-si e para-si se apresentassem em um estado de desintegração em relação a uma síntese ideal. Não que a integração jamais tenha tido lugar (eu lieu), mas precisamente ao contrário, porque ela é sempre indicada, e sempre impossível (EN, p. 671). 
Deste modo, assistido por este viés, ainda que Sartre rejeitasse por completo uma metafísica frente a sua ontologia, e mesmo que ele discuta e resolva problemas da tradição Metafísica pela ontologia, ele não consegue desvincular-se por completo do problema do fundamento. Assim, a relação entre ontologia e metafísica permaneceria ambígua, ${ }^{9}$ mas parece certo que não haveria uma dissociação absoluta entre elas. E mais, se Sartre realmente fosse apenas um crítico da Metafísica tal como Cox e Jeanson veem-no, então, ele não teria conseguido seguir com extremo rigor sua intenção. Essa foi a intuição de Heidegger:

Sartre, pelo contrário, exprime assim o princípio do existencialismo: a existência precede a essência. Ele toma, ao dizer isto, existentia e essentia na acepção Metafísica que, desde Platão, diz: a essentia precede a existentia. Sartre inverte esta proposição. Mas a inversão de uma frase metafísica permanece uma frase metafísica. Com esta frase, permanece ele com a Metafísica, no esquecimento da verdade do ser (HEIDEGGER, p. 14).

A afirmação de Heidegger poderia ser contestada pelo modo como Sartre trata esses dois conceitos e o de Ser, e pela primazia dada à contingência. Todavia, essa mesma crítica não permanece unicamente nos conceitos de essência e existência. Haar, por exemplo, continua nessa perspectiva heideggeriana e estende-a: "a razão da ingenuidade sartriana deve-se a sua tomada não crítica dos termos da metafísica" (HAAR, p. 56). Assim, embora se tenha sugerido aqui um debate de Sartre com a Metafísica, na perspectiva de Haar, tal empreitada não seria suficiente para escapar a uma ingenuidade. Essa ingenuidade sartriana,segundo ele, estender-se-ia a toda sua filosofia, isto é, por mais que Sartre faça críticas à Metafísica, sua filosofia não apresentaria caráter pós-metafísico, e isto por diversos motivos:

Sartre retoma, repetindo ingenuamente, pois não pensa a essência da metafísica, os principais axiomas das filosofias pós-cartesianas: a presença transparente e autossuficiente do sujeito a si mesmo; a evidencia desta presença a si (o cogito) como fundamento último do ser do saber; a autoafeição pela qual o sujeito é assegurado da certeza de si; o dualismo do eu e do não-eu; e, por fim, um humanismo ou antropomorfismo, graças ao qual o sujeito humano elevado a absoluto é fonte única de todo sentido (HAAR, p. 55).

\footnotetext{
${ }^{9}$ Em suas análises, Barbaras deduz que as dificuldades que ele mesmo encontra parte do enigma da diferenciação entre ontologia e metafísica: "No entanto, me parece que há em Sartre um enigma da distinção e da relação entre ontologia e metafísica" [...] (BARBARAS, 2003, p. 63).
} 
Deste modo, se, por um lado, veem-se comentadores como Jeanson e Cox afirmando que a filosofia de Sartre é contrária a qualquer proposta metafísica, seja pelo modo como Sartre a entende em sua obra, seja pelo modo como postulado segundo a tradição; vê-se, por outro, primeiramente, uma atitude de desconfiança e perplexidade ante a relação entre ontologia e metafísica, por Barbaras, e um posicionamento contrário ao de Cox e Jeanson, que levará, por exemplo, Haar (p. 63) a classificar a filosofia de Sartre como um "Dogmatismo antropo-teológico".

É claro que seria precipitado levar ao extremo essa ingenuidade de Sartre, equivaleria a dizer que ele não tem total consciência do terreno onde está pisando. Como foi visto, ele não apenas aceita todos os axiomas da Metafísica. Ainda que haja apenas uma inversão como o quer Heidegger, isso não significa que não haja sérias mudanças nesses conceitos. Seria mais sensato dizer que esses dois extremos, Sartre apenas como crítico da Metafísica ou somente um metafísico ingênuo, são, de fato, uma leitura ingênua da filosofia de Sartre. Embora ainda não menos forte que esses pontos de vista, há um situado nesses dois extremos: Sartre como caudatário à Metafísica e crítico desta.

Gerd Bornheim, em seus mais diversos textos, sempre frisou, com muita lástima, certa injustiça por parte de teóricos da filosofia ante as obras de Sartre. Na maioria das vezes, eles tomariam o existencialismo apenas como uma filosofia secundária, já que,para eles,Sartre não passaria de um comentador de Husserl e Heidegger, e sua filosofia não seria mais que uma mistura da filosofia deles e de outros. Mas, nesse caso, como compreender em um nível adequado a filosofia de Sartre?

É certo que se Sartre escreve filosofia é em um determinado contexto, e sua problemática é partidária dele. Mas qual contexto seria capaz de dar uma visão geral e adequada da filosofia de Sartre? Sabe-se que a fenomenologia é um marco para Sartre, e é a partir dela que ele desenvolve seus estudos iniciais e mesmo O Ser e o Nada. Mas nesse ponto parece que a sua releitura de Heidegger e Hegel seriam mais importantes.Bornheim propõe uma análise da filosofia de Sartre dentro da história da Metafísica, isto é, qual o lugar real que ele ocupa dentro da história da Metafísica. Isso implica não apenas um levantamento das influências sofridas por Sartre. Só isso seria insuficiente para caracterizar qualquer filosofia em seu aspecto mais originário. Nesse sentido, as análises de Bornheim revelam um caráter extremamente originário e profícuo. Isso porque ele não se limita a definir se Sartre é um metafísico $x$ ou $y$, ou ainda, partidário do conjunto $a$ ou $b$. Sua análise parte do pressuposto de que "há um sentido da evolução da Metafísica do qual Sartre permanece caudatário" (BORNHEIM, p. 134). Evolução porque, 
segundo ele, os problemas enfrentados por Sartre são os mesmos do platonismo, por isso, essa evolução será concebida como um momento de "radicalização do platonismo"; e isto não somente no sentido de analisarse e demonstrar a parcela de Platão presente em Sartre, mas sim, "em que sentido Sartre determina o platonismo" (BORNHEIM, p. 146). O foco de análise é centrado e conduzido pela questão da crise do fundamento, que, para Bornheim (p. 151) "a mais importante manifestação em nossos dias pode ser vista exatamente no pensamento de Sartre". Assim, dois são os problemas norteadores de tal análise: a contingência do em-si (e isso é importante para observar que a questão da contingência não é deixada de lado, mas ela mesma modifica-se ao tomar-se o fundamento como um problema além da contingência), e consequente deste, a impossibilidade de uma fundamentação do ser do para-si. Em termos platônicos, a participação é frustrada.

Bornheim faz uma analogia da intencionalidade enquanto nadificação com a ideia de participação como em Platão. Na medida em que a consciência permanece como outra que não o ser, surgindo a partir dele e direcionando-se a ele, e sendo contingente o fato de tal aparecimento, tudo se passa como se a consciência em seu movimento ao ser tendesse ao ser, necessitasse do ser, e, como surge sem fundamento, só encontrasse no ser seu fundamento. Mas, em que sentido entender isso?

A tessitura do fundamento manifesta-se na possibilidade de sua dicção. Se, em Platão, o outro que não o ser só tem ser na medida em que participa do ser, e é dessa relação que decorre a possibilidade de dicção, isto é, a legitimação da episteme, em Sartre, a questão torna-se complicada, já que o outro que não o ser não alcança o ser, no sentido de que a dicção enquanto fundamentada no ser acaba sendo tautológica, pois o ser é opaco, simplesmente é. Toda a fundamentação acaba sendo deixada a cargo do para-si, isto é, a dicção funda-se na contradicção. Em termos sartrianos, só há fundamentação do para-si enquanto nada, enquanto maneira de ser da consciência, isto é, enquanto ela explicase pelo próprio poder nadificador que define o para-si. ${ }^{10}$ Isso remarca a impossibilidade de ultrapassar o plano da simples aparência, a fenomenologia aparece como única fonte de possibilidade para uma análise. Daí o fato de que, tanto no caso do para-si como no caso do em-si, a dicção do fundamento, enquanto fundamento do ser, fica vedada. É a impossibilidade de uma fundamentação que assegura o não ultrapassamento do plano fenomenológico: “a fundamentação última do para-si seria realizável se fosse possível estabelecê-la a partir

\footnotetext{
${ }^{10}$ A consciência não pode ser "fundamento de seu ser-como-nada-de-ser", mas apenas "funda perpetuamente seu nada-de-ser" (EN, p. 667).
} 
do fundamento; só assim se transcenderia o plano fenomenológico" (BORNHEIM, p. 145).

Mas, nesse caso, como então explicar o surgimento do para-si? Daí as complicações da relação entre ontologia e metafísica como visto anteriormente. Essa é, segundo Bornheim, umas das maiores complicações da filosofia de Sartre, pois "se a pergunta fica sem resposta, o para-si deixa de ser fundamentado e, assim, a tarefa de uma ontologia negativa, do nada, torna-se inelutável" (BORNHEIM, p. 143), mas, em caso contrário, como foi visto, a questão da fundamentação da realidade torna-se problemática, pois sendo desenvolvida no contexto de uma ontologia do ser, finda-se "no impasse de uma tautologia". Isso, também, já aponta que a própria postulação da questão torna-se problemática: "se o ser não pode ser dito, muito menos se pode esclarecer como o nada possa surgir no seio do ser" (BORNHEIM, p. 144). Nesse caso, parecem realmente fechadas as portas para uma metafísica. Mas, segundo Bornheim, a questão é mais complexa:

A diferença fundamental que há entre Platão e Sartre é que, neste, a dicção do fundamento não se verifica mais, passa a ser mera tautologia. De fato, porém, o existencialismo se situa numa linha integralmente platônica. A questão central aqui pode ser formulada da seguinte maneira: por que a dicção do fundamento em Sartre torna-se impossível? $\mathrm{Na}$ hipótese de que tal dicção fosse restabelecida, toparíamos com um sistema à maneira da Metafísica tradicional. Tudo se passa, pois, como se o impasse a que chega Sartre fosse o impasse do próprio platonismo, da crise do todo da Metafísica Ocidental. Não obstante isso, o pensamento existencialista permanece inteiramente platônico no sentido de que ele se comporta como se a Metafísica devesse ser possível, ou seja, a impossibilidade da Metafísica justifica o absurdo apregoado em O Ser e o Nada (BORNHEIM, p. 145).

Esse aparente paradoxo contextualiza-se na impossibilidade de vencer a separação ontológica. Para deixar mais claro, Bornheim faz um contraponto da questão da separação com a do monismo, mostrando, para isso, a aproximação e o distanciamento de Sartre com relação a Hegel.

A premissa consiste em que a Metafísica sempre busca superar a separação a favor do monismo. Isso significa que ela sempre concebe a primazia do princípio de identidade sobre o de contradição. Mesmo Hegel ao ter dado grande ênfase ao princípio de contradição, não o sobrepõe absolutamente ao de identidade: ele busca a síntese. ${ }^{11}$ Se a negação é

${ }^{11} \mathrm{O}$ fundamento é a unidade da identidade e da diferença; a verdade daquilo que como se produziu a diferença e a identidade: a reflexão sobre si, tanto como a reflexão-sobre-o-outro; e vice-versa. É a essência posta como totalidade (HEGEL, p. 237). 
um momento essencial, significa que se parte da "contradicção", mas para além dela. Bornheim acredita que, desse modo, já aparecem em Hegel os primeiros indícios da crise do fundamento, pois a supressão da separação em direção à dicção absoluta resulta no monismo, isto é, na supressão do discurso: "podemos dizer, portanto, que o discurso filosófico permanece como que suspenso entre dois silêncios: deriva de um fundamento que lhe é anterior e se encaminha para seu próprio sacrifício [...] em última análise, não existe dicção do fundamento metafísico" (BORNHEIM, p. 153). Mesmo que o real volte a "dialetizar-se", ou seja, mesmo que Deus assuma o negativo, e por isso ao menos nesse momento o fundamento possa ser dito, isso não deixa de trazer sérias consequências. Dizer que o fundamento só pode ser dito enquanto Deus faz-se compatível ao processo dialético, é o mesmo que dizer que "o fundamento só pode ser dito na medida em que não é suficientemente fundamento" (BORNHEIM, p. 154). Isto é, somente na medida em que é finitizado, mas ai já se impossibilita a fundamentação absoluta. Nesse caso, haveria apenas a busca de um fundamento absoluto, mas jamais se completaria a negação da negação: "Hegel não consegue vencer o “solitário sem vida'". Se a dicção só pode ser dita com a contra-dicção, suspensa a última, a primeira também cessa, isto é, a dicção absoluta identificada ao monismo resulta num mutismo absoluto.

Segundo Bornheim, Sartre teria radicalizado tal processo. Se, em Hegel, a tese abriga a antítese - a afirmação do ser resolve-se em seu contrário que se encaminha à síntese, em Sartre, o processo é interrompido desde o início: o em-si é independe de sua fenomenalidade, o para-si não alcança a contingência do em-si, que permanece fechado em si mesmo. A cisão é radical e toda tentativa de superação é frustrada. Em Hegel, haveria ainda, a despeito de todas as complicações, um otimismo ontológico, uma vontade de vencer a separação. Por isso, Sartre permaneceria hegeliano, mas também iria além dele: ele não só veda o acesso à dicção absoluta, como, no fundo, está dizendo que "Hegel se tornou impossível: isto porque a dicção absoluta é impossível e absurda", mas permanece hegeliano na medida em que "reconhece que essa aspiração não pode ser extirpada do homem". Por isso, concluirá Bornheim, Sartre permanece "metafisicamente antimetafísico", ou ainda, que a Metafísica nele é resolvida "negativamente". Ao fixar-se na impossibilidade de superar a separação, ele radicaliza a proposta esboçada por Hegel; do pensamento do monismo passa-se à problemática da separação radical. Mas, o que leva a essa insuperável separação? Isto é, por que a participação entra em crise?

A crise da participação é uma consequência da crise do processo de entificação do ser. Todo o processo de elucidação do fundamento 
tem como critério a compreensão de um ente qualquer como medida do real e pelo qual se alcança a verdade de toda a realidade. É desse modo que ela consegue resolver questões como o da multiplicidade dos entes, uma vez que ele reenvia à questão ontológica, isto é, não considerando o ente em sua particularidade, mas por meio da unidade ascende-se do ente ao seu fundamento. ${ }^{12}$ A questão é que, "entificado o ser - como Ideia, Ato puro, Causa sui, Espírito, etc, -, a finitude do finito é esquecida, e a Metafísica passa a ser onto-teo-logia [...] porque, em verdade, a Metafísica nunca diz propriamente o finito; quando diz o finito, diz apenas o infinito presente no finito (BORNHEIM, p. 182). Por que crise da entificação? Porque, como foi visto, a dicção só é possível pela contra-dicção, o fundamento nunca é suficientemente fundamento: "a infinitização do finito acarreta a finitização do infinito" (BORNHEIM, p. 183). Essa tese, que é uma tese Metafísica, é bastante forte e mesmo perigosa sobre o pensamento de Sartre. Primeiramente, porque, em nenhum momento, Sartre contrapõem esses dois elementos de modo explícito e direto; segundo, porque uma filosofia que se quer ainda como fenomenologia carrega em si a característica de uma filosofia da finitude, já que não supera (e não há porque superar) os perfis apreendidos pela consciência. Entretanto, ainda que pareça confuso o fato da discussão de Sartre com a Metafisica, a relação entre ontologia e metafísica, conforme ele estabelece e dessas para com a tradição, o problema do surgimento do para-si e o lugar do ideal de ens causa sui, a tese esboçada por Bornheim não só corrobora a intuição da discussão desse trabalho, como rebate fortemente a intenção originária do próprio Sartre ao pressupor essa relação entre finito e infinito. Bornheim defende a tese de que Sartre não ascende à elucidação da "finitude do finito" (BORNHEIM, p. 193), isto é, pensa o finito somente em contraposição ao infinito.

Deste modo, se Prado Junior (2003, p. 11) afirma que Sartre "declara a morte do principio de razão suficiente", é preciso, entretanto, convir que ele não consegue abandonar a sua sombra, porque ainda que o ideal em-si-para-si seja contraditório, tal como foi visto, é por ele que Sartre pensa a relação originária entre em-si e para-si, tema principal da obra segundo a própria Introdução. Deste modo, dever-se-ia, ao menos,

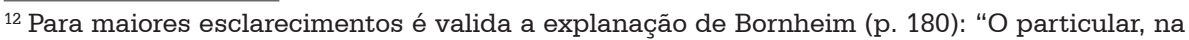
medida em que for reduzido à sua própria particularidade, tornar-se-á estritamente absurdo; nesse sentido, o particular exige, desde o fundo de sua particularidade, um contexto no qual se possa inscrever - este o tema que a tradição elucida através de conceitos como analogia e participação". É interessante que o em-si, em Sartre, basicamente assume essa particularidade de forma extrema: nele, não há relação, nem interna, consigo mesmo, nem externa. Do mesmo modo, a existência como para-si mostra-se absurda porque acaba sendo resumida na sua particularidade: o sentimento de solidão e desamparo representam essa nostalgia da finitude.
} 
tomar certa cautela ao afirmar que a filosofia de Sartre é uma filosofia da finitude positiva, ao menos em sua fase ontológica. Não que ele não pense a finitude, muito pelo contrário, a finitude é sim o tema principal, mas o problema é o como ela é abordada, pois, desse modo, para Bornheim, Sartre mostrar-se-ia platônico, e, portanto, Metafísico, por quatro motivos: primeiro, porque seu pensamento apresenta teor de uma onto-teo-logia; em segundo, desdobra-se nos quadros das dimensões instauradas pela entificação do ser; em terceiro, é o estatuto da entificação que determina o da participação; e em quarto, conserva-se metafísico, no sentido de que trata a separação no âmbito metafísico, isto é, "em Platão e Sartre há uma premissa monista" (BORNHEIM, p. 186). Nesse sentido, a filosofia de Sartre mostra-se paradoxal: ela apresenta características de uma onto-teo-logia, já que, embora pela fenomenologia Sartre busque elaborar uma filosofia da finitude, ele não consegue desvincular-se dos axiomas da Metafísica, e ainda insere o problema do fundamento no cerne de sua teoria. Além disso, ele parte da entificação do ser, e, embora seu objetivo seja mostrar a impossibilidade da fundamentação absoluta, que o em-si contingente reenvia à separação radical, ele demonstra que a realidade constitui-se de tal separação, por isso não vai além da Metafísica; portanto, como já foi dito, "sua filosofia é uma Metafísica antimetafísica" (BORNHEIM, p. 183).

Como entender esse paradoxo? Se ele não supera a Metafísica, como entender o avanço de sua filosofia em relação a de Hegel? É que "de dentro do processo autodestrutivo se impõe com necessidade a radicalização do platonismo" (BORNHEIM, p. 189). Essa radicalização é justamente a "reivindicação da finitude". Se Heidegger fala de um esquecimento do Ser, pode-se dizer que Sartre fala de um esquecimento do nada, daquilo que não é redutível ao ser, do outro que não o ser. Não que o ser deva ser esquecido ou ter um grau menor em uma suposta hierarquia, pelo contrário, há "uma prioridade ontológica do ser sobre o nada" (EN, p. 667), já que toda nadificação dá-se sobre um fundo de ser, e o próprio para-si nada mais é que o "em-si nadificado". Mas, como afirmará Sartre, "o problema permanece o mesmo em todas as teodicéias: é necessário inocentar Deus. Contudo, não é suficiente colocar de um lado o Bem, o Verdadeiro, a Ordem, o Objetivo, o Ser, e, de outro, o Mal, o Erro, o Subjetivo, o Nada: é necessário dar conta do Nada [...]" (Sit. VI, p. 44). Com a crise da entificação, a questão do nada ganha um relevo maior, pois ele não é resolvido pela Metafísica. Por isso, a filosofia de Sartre é uma metafísica às avessas, e o sentido da inversão reside não apenas numa mudança aparente de uma tese clássica, como o quis Heidegger, trata-se, antes, de um autêntico problema filosófico: pensar a questão do nada ante a crise metafísica do fundamento, ou, pensar a finitude na 
medida em que a impossibilidade de deus faz-se presente no horizonte da experiência finita que é a existência humana. A aventura humana é um ato de causação pelo qual o real busca constituir-se como causa de si.

Todavia, as próprias dificuldades fenomenológicas e delas a necessidade de sua radicalização ontológica demonstram que uma fenomenologia do nada seria impossível, e a partir do momento que o ser da consciência não se confunde com o ser do transcendente, mas o exige, torna-se impossível a separação entre ser e nada, fenômeno e Ser, finitude e infinitude. É somente assim que há como pensar o nada: é o não abandono da questão do ser que faz com que Sartre possa pensar o nada, por isso ele não dispensa a Metafísica, pois ele não pensa o finito a despeito de tal crise, não há uma ascensão à elucidação da "finitude do finito" (BORNHEIM, p. 193). Assim, Sartre pensaria sim a finitude, e seu objeto é a finitude, mas como já demonstrado, toda caracterização da finitude do homem como para-si é desenvolvido constantemente com dualismos: perfeito e imperfeito, possível e necessário, contingência e fundamento, que, no fundo, remetem inevitavelmente a do finito (para-si como falta de ser) e infinito (em-si-para-si como si do para-si enquanto falta).

\section{IV}

Assim, essa ligação entre finito e infinito é posta pela própria consciência: se ela é puro fazer, esse fazer-se da consciência tem que ter uma motivação que não pode ser a simples distância do em-si, deve haver ao menos um horizonte de reconciliação, o desejo não pode ser desejo de distância. Mesmo pensado de forma negativa, o sertodo, como quase-totalidade, permanece com seu espectro na realidade. Sartre não dispensa o conceito de causa sui, pois mesmo o para-si, abandonado a sua própria finitude, é compreendido em contraposição a sua infinitude, ainda que essa seja apenas hipoteticamente constituída. Por isso, em certo sentido há uma finitização do infinito: mesmo que o ideal de causa de si seja contraditório, Sartre não consegue desligar-se dele por completo. É este fato que acarreta a impossibilidade de pensar-se o finito em sua irredutibilidade: há, em Sartre, de forma paradoxal, uma metafísica da finitude. Da ontoteologia de Sartre resulta a finitização do Deus metafísico:

Cada realidade-humana é ao mesmo tempo projeto direto de metarmorfosear seu próprio para-si em em-si-para-si e projeto de apropriação do mundo como totalidade de ser-em-si, sob as espécies de uma qualidade fundamental. Cada realidade-humana é uma paixão, já que projeta perder-se para fundamentar o ser e para constituir, ao mesmo 
tempo, o em-si que escape à contingência sendo seu próprio fundamento, o Ens causa sui, que as religiões chamam de Deus. Assim, a paixão do homem é inversa à de Cristo, pois o homem se perde enquanto homem para que Deus nasça. Mas a ideia de Deus é contraditória, e nos perdemos em vão; o homem é uma paixão inútil (EN, p. 662).

Em suma, o monismo passa a ser um ideal utópico. A realidade como impossibilidade de superar a separação é fundamentada por essa utopia. O para-si aparece como única forma possível de fundamento, ainda que seja como nada de fundamento. Fundamento este que é assombrado pelo ideal de fundamentação absoluta e constitui-se como perseguição a este. Vale a pena enfatizar novamente: é decretado o fim do princípio de razão suficiente, sem, no entanto, livrar-se de sua sombra. Sartre não só se depara com questões metafísicas, tais como ele compreende, como sua filosofia não se desvincula da Metafísica: "trata-se sempre da mesma recusa da finitude do finito, e sempre da reiterada tentativa de divinizar o real e especialmente o homem [...] Assim, a nostalgia do Deus metafísico é - metafisicamente - a causa última do pensamento de Sartre" (BORNHEIM, p. 215).

Em suma, O Ser e o Nada é uma obra que não só discute questões metafísicas e com a Metafísica, como não consegue superá-la completamente, e é por essa via que se pode compreender sua dimensão original:

Ele nos permite compreender como ninguém o impasse a que chegou a Metafísica. Entenda-se, contudo, que o impasse não está simplesmente em Sartre ou neste livro O Ser e o Nada; as dificuldades da Metafísica não dependem das ideias de um homem particular, se com isso se pretende que elas só se tenham tornado possíveis porque nosso autor escreveu o seu livro [...] de resto, como já acentuamos, nem se trata apenas do destino de uma disciplina filosófica, e sim do próprio sentido da Cultura Ocidental (BORNHEIM, p. 206).

Assim, há dois caminhos que tendem para o mesmo fim. Seja partindo da fenomenologia ou comprometendo-se na discussão com a metafísica, o alvo de Sartre é a finitude. A diferença é que enquanto se pressupunha que, no primeiro, se conseguiria isso desvinculado de uma linguagem metafísica, o segundo já pressupõe o contrapé da finitude, isto é, o conceito de infinitude. Sartre não se refere a este conceito diretamente, e mesmo a sua definição de metafísica não penetra diretamente neste ponto, já que é apenas hipotética. Entretanto, ao abordar, e mesmo postular, ainda que apenas como ideal, um fundamento absoluto, Sartre, como percebeu Heidegger, Haar e Bornheim, não se desvincula da 
Metafísica; e acrescente-se, pois ele não pensa a finitude unicamente nela mesma, mas por contraposição a um ideal de fundamento absoluto.

A proposta de uma fenomenologia que traria indiscutivelmente o caráter de uma filosofia da finitude acaba por postular um ideal de fundamento, o ens causa sui, ou o desejo de ser Deus, como estrutura profunda da realidade-humana. Sartre, ao constituir sua crítica à fenomenologia, onde, segundo ele, ela caía num dualismo entre finito e infinito, recai, por fim, no mesmo dualismo criticado para poder compreender o sentido da relação entre as duas dimensões transfenomenais do fenômeno e a própria fenomenalização do ser; com a diferença de que se, em Husserl,ele criticava a necessidade de postular-se um infinito quantitativo, por sua vez, postula um infinito qualitativo. Numa linguagem propriamente metafísica, Sartre define a realidade-humana como consciência infeliz, já que ela deseja ser algo que, por sua própria estrutura, éimpossível, restando apenas o fracasso perpétuo desta tentativa incansável e a constante alienação do homem pelo valor e pelo Ser. Sendo livre, mas perdido pelo mesmo motivo de seu surgimento como livre, o homem é uma paixão inútil.

O maior problema que isso acarretará diz respeito ao problema moral enquanto realização da vida autêntica, uma vez que o Ser conduz à má-fé, e esse mesmo não pode ser erradicado da experiência humana, a própria autenticidade e a finitude ficam ameaças em sua possibilidade, pois ainda que particular e finita toda sua verdade diz respeito a uma estrutura absurda e impossível, restando somente o fracasso ontológico da ação, advindo de uma liberdade que se perde para fundar o Ser. No entanto, à maneira sartriana, este estudo exige a análise de questões cujo escopo foge a dimensão deste trabalho.

\section{Referências}

BARBARAS, R. "Désir et manque dans L'Être et le Néant: le désir manque". In: BARBARAS, R. Sartre-Désir et liberté. France: Presses Universitaires de France, 2005.

. Vie et intentionnalité - recherches phénoménologiques. France: Librairie Philosophique J. Vrin, 2003. (Problèmes \& controverses).

BORNHEIM, G. Sartre: metafísica e existencialismo. 3. ed. São Paulo: Perspectivas, 2003.

COX, Gary. Compreender Sartre. Tradução de Hélio Magri Filho. Petrópolis: RJ: Vozes, 2007.

HAAR, Michel. La philosophie française entre phénoménologie et metaphysique. Paris: PUF, 1999.

HEGEL, G. W. F. Enciclopédia das ciências filosóficas em compêndio. Vol. I - A ciência da lógica. Tradução de Paulo Meneses. São Paulo: Loyola, 1995. 
HEIDEGGER, M. Carta sobre o humanismo. Tradução de Rubens E. Frias. São Paulo: Editora Moraes, 1991.

HUSSON, Laurent. "De la contingence à la situation: dimensions et configutations de la facticité dans L'Être et le Néant". In: MOULLIE, J-M, Sartre et la phénoménologie. France: ENS Editions, 2001.

LOPARIC, Zeljko. Ética e finitude. 2. ed. São Paulo: Escuta, 2004.

MOUTINHO, Luiz D. S. Sartre: psicologia e fenomenologia. São Paulo: Brasiliense, 1995.

PRADO JUNIOR, Bento. "Sartre e o destino histórico do ensaio" (Prefácio). In: SARTRE, J.-P. Situações I: críticas literárias. Tradução de Cristina Prado. São Paulo: Cosac Naify, 2005.

. "O circuito da ipseidade e seu lugar em O ser e o nada". In: Dois Pontos: Sartre,

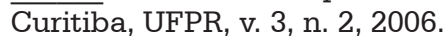

SARTRE, J-P. L'être et le néant - Essai d'ontologie phénoménologique. France: Gallimard, 2007. . Cahiers por une morale. France: Gallimard, 1983. . Situations VI. Paris: Gallimard, 1964.

SILVA, Franklin Leopoldo e. Ética e literatura em Sartre - ensaios introdutórios. São Paulo: UNESP, 2004.

SOUZA, Luiz Henrique Alves. O estatuto da reflexão em Sartre. Tese (Doutorado) Universidade Federal de São Carlos, São Carlos, 2009.

\section{Endereço postal:}

UNICENTRO - Departamento de Filosofia

Rua Padre Salvador, 875

85015-430 Guarapuava, PR, Brasil

Data de recebimento: 26/08/2013

Data de aceite: 27/05/2014 